\title{
Chainsaw Operator Training \& Occupational Safety and Health Socialization at Perum Perhutani KPH Banyuwangi Utara
}

\author{
Ikhwanul Qiram¹, Joko Suwondo² \\ 1 Universitas PGRI Banyuwangi \\ 2SMK Muhammadiyah 6 Rogojampi \\ Email: ikhwanul@unibabwi.ac.id
}

d.

https://doi.org/10.36526/gandrung.v2i2.1391

\begin{abstract}
Chainsaw operator is an important profession in logging production forest which has high occupational accident risk criteria. These potential risks can be in the form of accidents that are mechanical, electrical, biological, and physical. This community service activity is in the form of socializing chainsaw machine operational SOPs and introducing occupational health and safety as a preventive effort in reducing the potential risks faced by loggers in the Perum Perhutani KPH Banyuwangi Utara. This activity received quite a good appreciation for chainsaw operators in the Perum Perhutani KPH North Banyuwangi environment. The results of the training have provided basic knowledge about maintaining chainsaw machines and increasing safety first discipline for all parties involved in chainsaw operator activities.
\end{abstract}

Keyword: , Chainsaw operator, Occupational Health And Safety, Community service

Pendahuluan

Kesatuan Pemangkuan Hutan (KPH) Banyuwangi Utara merupakan salah satu unit kelola Sumber Daya Hutan (SDH) Perum Perhutani Divisi Regional Jawa Timur, Luas kawasan hutan KPH Banyuwangi Utara yaitu 50.506,68 Ha terletak di 2 (dua) Kabupaten, yaitu Kabupaten Banyuwangi seluas 28.134,26 Ha dan Kabupaten Situbondo seluas 22.372,42 Ha Provinsi Jawa Timur (Perum Perhutani KPH Banyuwangi Utara, 2021). Aktifitas produksi yang dilakukan oleh Perum Perhutani KPH Banyuwangi utarayang meliputi tahap penebangan, pembagian batang, pengangkutan dan penimbunan kayu.

Kegiatan pemanenan kayu adalah kegiatan yang meliputi penebangan, penyaradan, muat bongkar dan pengangkutan (Yuniawati, 2011). Proses ini banyak melibatkan aktifitas fisik yang cukup berat dantentunya berpotensi menimbulkan risiko tinggi kecelakaan kerja. wawasan keselamatan dan kesehatan kerja (K3) merupakan pengetahuan penting bagi pihak-pihak yang terlibatterutama operator Chainsaw sebagai pihak yang sangat rentan denganbahaya kecelakaan kerja. Hasil penelitian menunjukkan bahwaangka kecelakaan kerja pada kegiatan kehutanan 4 kali lebih besar dibandingkan angka kecelakaan pada industri lain (Gani, 1992). Resiko kecelakaan disebabkan oleh beberapa faktor yang saling berkaitan satu dengan yang lain, faktor yang saling berhubungan tersebut adalah 
GANDRUNG: Jurnal Pengabdian Kepada Masyarakat ISSN: 2721-6136 (Online)

manusia,peralatan dan lingkungan kerja (Pradipta, 2016). Aspek lingkungan meliputi kondisi alam tempat bekerja yang cukup beresiko seperti jalanan terjal dan sulit dilewati, resiko tertimpa pohon, ancaman binatang buas dan sebagainya.

Chainsaw (gergaji rantai) adalah alat potongkayu yang menggunakan mesin untuk menggerakkan rantai gergajinya(Pradipta, 2016). Mesin potong chainsawsangat memudahkan dan meningkatkan efisiensi waktu penebangan (Yuniawati, 2011). Seiring dengan perkembangan teknologi chainsaw didesain lebih kecil, ringan, bertenaga listrik, material bilah yang lebih ringan, tahan terhadap gesekan, tekanan dan panas serta performa mesin yang telah ditingkatkan. Teknologi ini dikembangkan dengan tujuanuntuk menunjang kenyamanan dan keselamatan kerja bagi operator chainsaw sekaligus menunjang produktivitas kerjanya (Matangaran, 2007).

Disisi lain, komitmen manajemen adalah aspek pendukung yang cukup berpengaruh terhadap tata laksana K3 di lapangan. Seringkali program keselamatan dan kesehatan kerja belum berjalan sesuai denganyang direncanakan sehingga justrurisiko kecelakaan kerja dapat meningkat dengan tajam. Oleh sebab itu, pencegahan resiko kecelakan kerja dilingkungan KPH Perhutani secara aktif terus dilakukan, bentuk aktifitas pencegahan yang dilakukan meliputi risk assessmentdan hazard identificationuntuk menilai tingkat risiko pada saat pengoperasian chainsaw. Salah satunya adalah tentang efek fisik akibat kebisingan dan getaran mesin (Muhibudin, 2012), analisis resiko pada aspek mekanis, elektrik, biologis dan fisik (Pradipta, 2016);(C, 2006);(Yovi EY, 2015), efisiensi operasi (Puspitasari, 2019), aspek eskternal yang mempengaruhi kondisi status ergonomi pekerja sektor kehutanan di indonesia (Yovi, 2019), penilaian postur kerja dan risikomusculoskeletal disorders(MSDs) pada kegiatan penebangan pohon jati(Pahlevi, 2018).
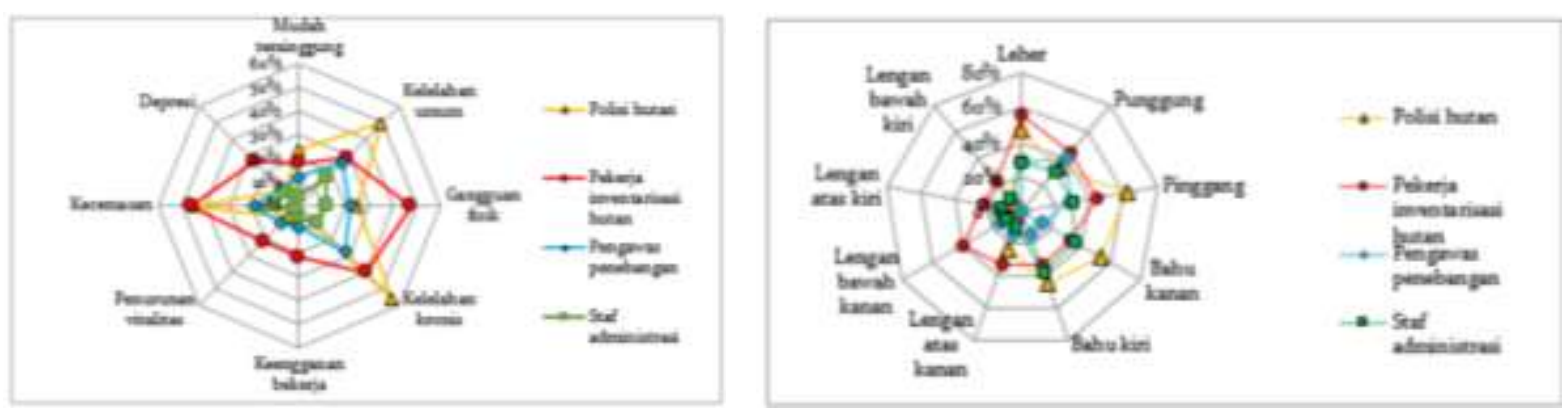

Gambar 1. Histogram survey keluhanfisik dan psikis pada kelompok yang terlibat dalam kegiatan penebangan pohon (Yovi, 2019)

Menurut Yovi, (2016), saat ini pekerja sektor kehutanan di Indonesia bekerja dengan fasilitas pendukung kerja yang dianggap belum sesuai dengan kebutuhan pekerja. Sehingga resiko gangguan K3 sering dikeluhkan oleh pekerja dalam bentuk kelelahan yang intens pada kondisi fisik dan mental 
GANDRUNG: Jurnal Pengabdian Kepada Masyarakat ISSN: 2721-6136 (Online)

serta gangguan otot (pinggang, punggung, leher, bahu kanan-kiri, serta lengan kanan dan kiri baik lengan bawah maupun atas). Untuk mengurangidampak buruk pekerja sektor kehutanan maka perlu adanya perhatian melalui upaya peningkatan perlindungan K3. Kegiatan sosialisasi harus didasari atas komitmen dan dilakukan secara berkelanjutan melalui berbagai program perlindungan K3 yang disusun dengan mempertimbangkan keterbatasan aspek kognitif dan relatif rendahnya kemampuan finansial pekerja.

\section{Metode}

Kegiatan ini pendampingan ini dilakukan sebagai salah satu upaya untuk refresh trainer pada operator chainsaw dilingkungan Perum Perhutani KPH Banyuwangi utara. Kegiatan dilakukan pada saat situasi pandemi Covid 19, sehingga kegiatan harus dibuat menjadi dua sesi dalam waktu yang berbeda mengingat banyaknya jumlah operator yang harus dilatih. Kegiatan ini tetap mengacu pada protocol Covid 19 karena didalam instrumen pelatihan juga mewajibkan seluruh peserta untuk mempraktekkan secara langsung. Adapun tahapan kegiatan meliputi alur sebagai berikut :

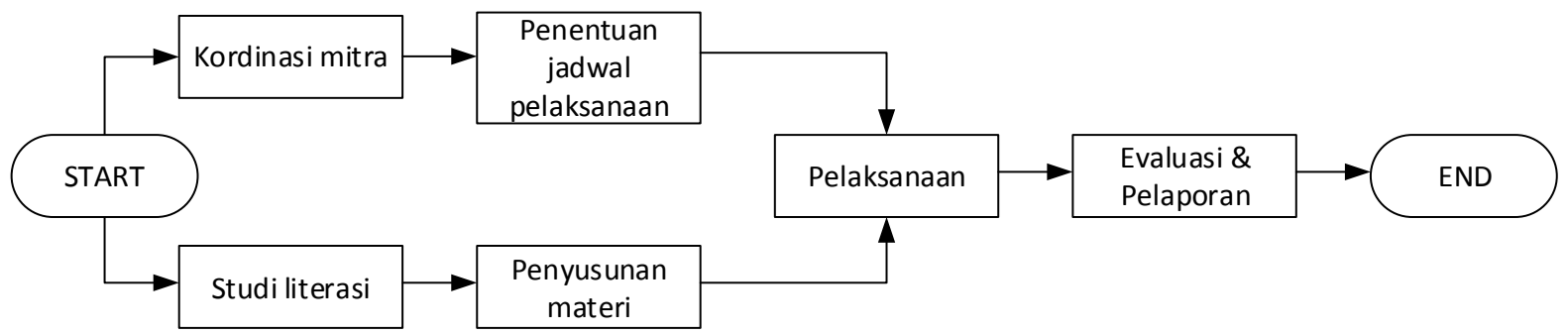

\section{Gambar 2. Alur kegiiatan pelatihan operator chainsaw Perum Perhutani KPH Banyuwangi Utara}

Kegiatanini dilaksanakan pada tanggal 10 Februari 2021 dengan melibatkan 15 operator dan unsur pimpinan Perum Perhutani KPH Banyuwangi Utara. Kegiatan sosialisasi dan pelatihan dilakukan dengan metode ceramah serta praktik langsung secara bergantian. Dalam kegiatan praktik, setiap operator didampingi oleh instruktur yang telah terlatih dan bersertifikasi.

Beberapa peralatan penunjang pelatihan meliputi, mesin chainsaw 5 unit, paket APD (alat perlindungan diri) 5 paket, dan sejumlah kayu gelondong jenis mahoni dan jati dengan beberapa ukuran sebagai media praktek. Selain itu setiap peserta juga dibekali dengan buku petunjuk dalam pengoperasian chainsaw dan manajemen K3 sebagai standart operasi di lapangan.

\section{Hasil dan Diskusi}

Kegiatan pendampingan ini dapat dilakukan melalui program kerjasama yang baik antara alumni beserta tim dosen pelaksana Program Studi Teknik Mesin Universitas PGRI Banyuwangi 
GANDRUNG: Jurnal Pengabdian Kepada Masyarakat ISSN: 2721-6136 (Online)

dengan Perum Perhutani KPH Banyuwangi Utarasehingga dari proses asassment lapang hingga pelaksanaan dapat terlaksana dengan baik. Seluruh kegiatan difasilitasi melalui Anggaran dasar Perum Perhutani KPH Banyuwangi Utarayang meliputi pendistribusian undangan, penyediaan material, hingga sarana dan prasarana pelatihan.

Kegiatan ini dibuka oleh Pimpinan Perum Perhutani KPH Banyuwangi Utarayang dilanjutkan dengan sosialisasi K3 sebagai bentuk komitmen institusi terhadap keselamatan dan kesejahteraan para operator chainsaw. Dalam paparannya, pihakPerum Perhutani KPH Banyuwangi Utaramasih seringkali menemukan berbagai bentuk aktifitas diluar dari SOP seperti halnya kelalaian penggunaan helm dan sarung tangan dengan alasan ketidaknyamanan yang justru meningkatkan resiko kecelakaan kerja yang dihadapi semakin tinggi. Selain itu temuan lain yang mendapat perhatian serius adalah penurunan kondisi fisik dan mental kelompok operator yang terlibat dalam kegiatan penebangan pohon.Berbagai temuan ini akan berdampak terhadap resiko hilangnya pendapatan yang memicu kerugian secara langsung bagi pekerja. Maka dari itu aspek kebugaran fisik yang ditunjang melalui pola asupan nutrisi, pola istirahat yang cukup dan alat perlindungan diri saat berkerja menjadi prioritas utama dalam materi di sesi ini.
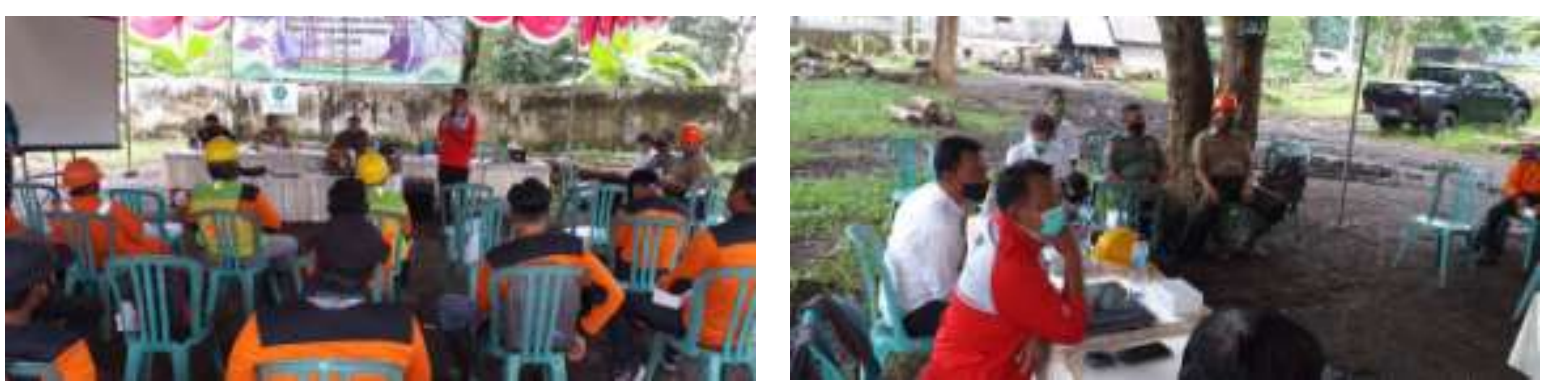

Gambar 3. Kegiatan sosialisasi K3 pada operator chainsaw di Perum Perhutani KPH Banyuwangi Utara dan jajaran terkait

Pada sesi berikutnya, peserta diberikan pelatihan tentang tata laksana penggunaan chainsaw yang meliputi pemahaman tentang prosedur keamanan dan keselamatan kerja yang berhubungan dengan penggunaan chain saw,prosedur pemeliharaan dan pengecekan kesiapan chain saw, pemahaman teknik menebang dengan tepat dan aman, teknik pemotongan kayu yang akurat dan aman dan efisien. Berdasarkan hasil evalusi ditunjukkan bahwa pemangku Perum Perhutani KPH Banyuwangi Utara merespon positif kegiatan ini. Hal senada juga disampaikan oleh kelompok operator chainsaw dimana meskipun program sertifikasi operator telah dimiliki namun perlu ada refresh tarining yang berkelanjutan untuk dilakukan. 

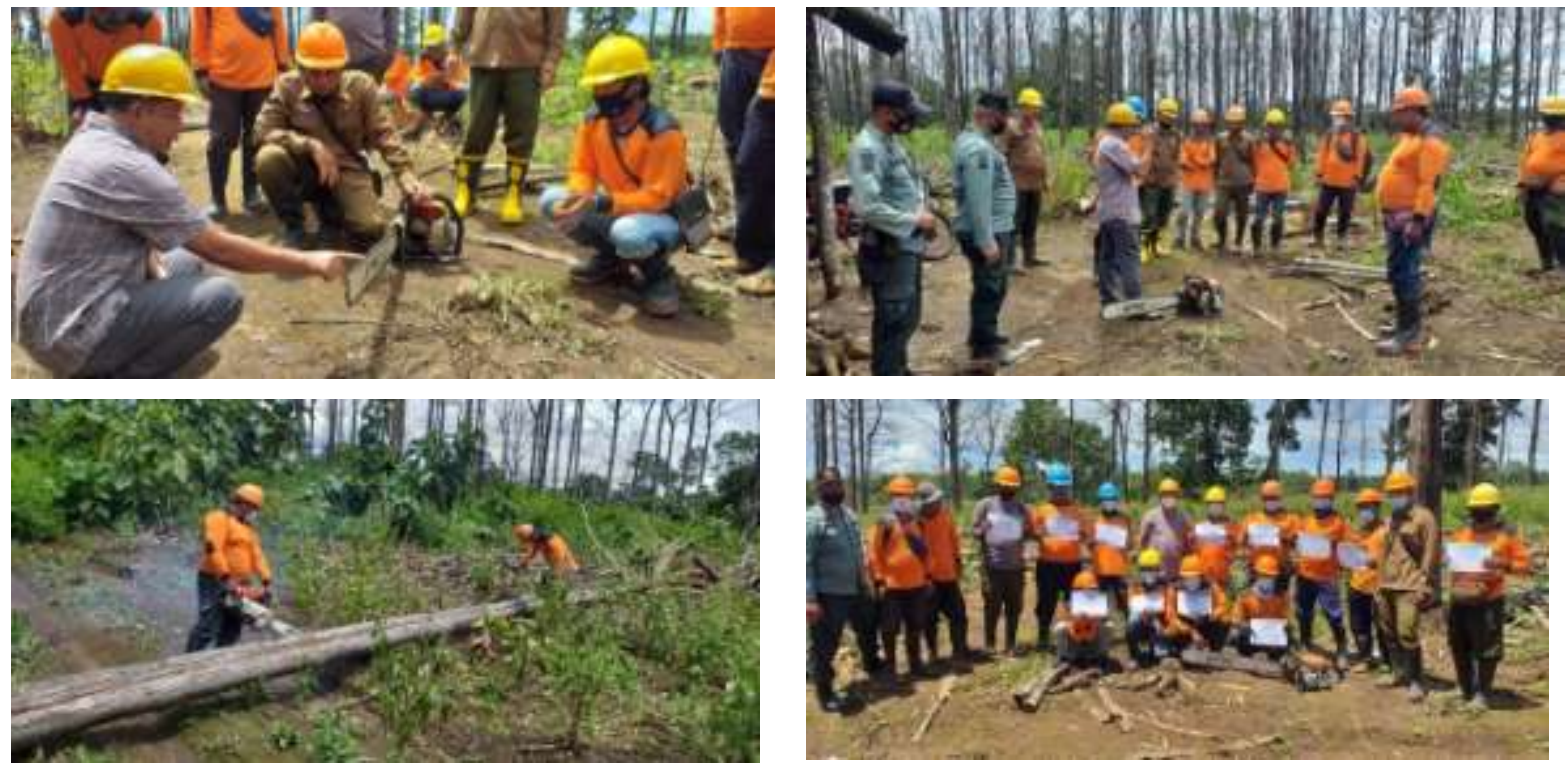

Gambar 3. Pelatihan operator chainsaw pada Perum Perhutani KPH Banyuwangi Utara

Namun terdapat beberapa hal penting yang direkomendasikan oleh para oprator chainsaw, dimana pada umumnya mereka bekerja rata-rata 8 jam/hari dan seringkali harus lembur meski walau pada hari libur. Disisi lain para operator juga membutuhkan layanan pengecekan kesehatan secara rutin mengingat faktor usia dan lama aktifitas kerja. Menurut Briger (2003) menyatakan bahwa kondisi fisik manusia saat menginjak usia 30 tahun akan mengalami degenerasi tulang sehingga memicu berkurangnya stabilitas pada tulang dan otot.

\section{Kesimpulan}

Operator chainsaw merupakan salah satu keolmpok profesional dengan tingkat resiko kerja kategori tinggi dalam aktifitas penebangan kayukhususnya di Perum Perhutani KPH Banyuwangi Utara.Pengetahuan, ketrampilan dan sikap kerja yang baik dan benar seorang operatorchainsawmenjadi aspek penting yang tidak dapat diabaikan. Maka dari itudibutuhkan upaya peningkatan kapasitas (capacity building) pada operator chainsaw melalui kegiatan pendampingan secara berkelanjutan untuk menjaga performa usaha. Program sosialisasi dan pelatihan ini disusun tidak hanya secara teoritis tetapi juga dilakukan dengan kegiatan praktek sehingga materi yang diberikan bisa langsung diaplikasikan oleh para peserta. Hasil pelatihan ini secara khusus telah memberikan pemahaman terkait K3pengoperasian chain saw serta implikasinya terhadap kegiatan operasional di lapangan. 
GANDRUNG: Jurnal Pengabdian Kepada Masyarakat ISSN: 2721-6136 (Online)

\section{Daftar Referensi}

C, G. (2006). Work-Related Prevalence Of Musculoskeletal Symptoms Among Greek Forest Workers. International Journal Of Industrial Ergonomics.

Gani, S. (1992). Ketenagakerjaan Dan Keselamatan Kerja. Bogor: Ipb Press.

Matangaran, J. (2007). Pengetahuan Tentang Chainsaw (Prinsip Kerja Dan Pengoperasian). Bogor: Fakultas Kehutanan Ipb.

Muhibudin. (2012). Perlindungan Keselamatan Dan Kesehatan Kerja (K3) Dalam Kegiatan Penebangan Pohon Melalui Desain Sarung Tangan Untuk Operator Chainsaw. Bogor: Institut Pertanian Bogor.

Pahlevi, R. (2018). Penilaian Postur Kerja Dan Risiko Musculoskeletal Disorders (Msds) Pada Kegiatan Penebangan Pohon Jati Di Perum Perhutani Kph Madiun Jawa Timur . Bogor: Departemen Manajemen Hutan, Fakultas Kehutanan, Nstitut Pertanian Bogor.

Perum Perhutani Kph Banyuwangi Utara. (2021, 06 30). Kph Banyuwangi Utara. Retrieved From Www.Perhutani.Co.Id

Pradipta, R. A. (2016). Risk Assessment Pada Pekerjaan Menebang Kayu Di Hutan Produksi (Studi Kasus Pada Pengoperasian Chainsaw Perum Perhutani Kph Madiun). The Indonesian Journal Of Occupational Safety And Health, 153-162.

Puspitasari, T. (2019). Analisis Potensi Bahaya Dan Penilaian Risiko Di Project Management Unit. Semarang: Skripsi, Jurusan IImu Kesehatan Masyarakat, Universitas Negeri Semarang.

Yovi Ey, P. W. (2015). High Risk Posture On Motor-Manual Short Wood Logging System In Acacia Man Gium Plantation. Jurnal Manajemen Hutan Tropika.

Yovi, E. Y. (2019). Status Ergonomi Pekerja Sektor Kehutanan Di Indonesia: Kelelahan Fisik-MentalSosial, Kepuasan Kerja, Konsep Sumber Bahaya, Dan Konsep Biaya Kecelakaan. Jurnal IImu Kehutanan.

Yuniawati, S. S. (2011). The Use Of Efficient Logging Equipment At A Timber Estate Company In South Kalimantan. Jurnal Penelitian Hasil Hutan, 369-384. 